logos_i_ethos_2017_(45)_numer specjalny, s. 191-208

DOI: http://dx.doi.org/10.15633/lie.2346

Magdalena M. Baran

\title{
Reasoning and Moderation as Principles of International Humanitarian Law \\ (Part 1)
}

Thinking of war we can have in mind very different ideas. Starting from brutal revenge, desire of possession, through religious reasons, economic interests, private animosity up to a theory of just war and philosophical/ethical issues that I call tools of war. One may of course indicate a lot of them, starting from justice, that has became a frame for just war theory, but even this one de-

Magdalena M. Baran, dr, adiunkt w Instytucie Filozofii i Socjologii Uniwersytetu Pedagogicznego w Krakowie. Jej zainteresowania badawcze obejmują: filozofię wojny, etyki stosowane, filozofię polityczną i społeczną, historię idei. Stypendystka Instytutu Nauk o Człowieku w Wiedniu, Uniwersytetu Wiedeńskiego, Uniwersytetu w Siegen, Uniwersytetu w Würzburgu. Gościnny profesor na Uniwersytecie w Györ i Uniwersytecie w Murcji. Członek redakcji kwartalnika. mands a kind of measure, enable to limit the war as such. Looking for such a measurement we can indicate at least two ideas necessary to tame the war. Those are reasoning and moderation. Looking for their roots I chose two disciplines/fields appropriate to consider their meaning. Question about the reasoning and moderation should be asked by ethics, or better to say applied ethics of different professions (initially involving soldiers, war correspondents, and auxiliary personnel, and now extended to scientists, researchers, and politicians). The second realm, in which we ask about reasoning and moderation, is law, with particular subject to international humanitarian law and its applications to individual cases. Both fields are crucial for the understanding war and for shaping its fate. Focusing on modern international humanitarian law, understood as the one that grew on the philosophical theory of just war, one should 
examine its beginnings, to see the role of reasoning and moderation. If indeed (and probably no one doubts) "none of the moral excellences arises in us by nature; for nothing that exists by nature can form a habit contrary to its nature"1 and "excellence, then, is a state concerned with choice, lying in mean relative to us, this being determined by reason and in the way in which the man of practical wisdom would determine it," golden mean would be the main principle of both law and applied ethics.

Would it be easier to apply the golden mean to particular practical/ applied ethics than to international law? Not necessary, especially if we are willing to agree that such a law might be the extension ethical beliefs and that a) it grew on the understanding of particular virtues and values, b) was based on so called "requirements of humanity," c) was established as a result of reasonable analysis of previous wars, enormous and unexpected cruelty of one human against another, one state against another. Here we cannot forget that "justice is not included in the definition of war, because the very point to be decided is, whether any war is just, and what war may be so called." 3 But what if the division line is not that clear? If it's hard to find moderation and the codes of ethics and law have to adapt to the new challenges and requirements arising from practice? What if this "practice" is not only new but also scary and therefore difficult to grasp? If a world as we know it suddenly falls and there is a need to redefine it?

At the beginning of the twentieth century, the war and its techniques have undergone a profound transformation. "Never before has the number of civilians in towns and villages become the target - with the deliberate choice - of murderous mass destruction measures" - about the devastation caused by using the new assortment of arms of the Great War wrote Jerzy Pomianowski. ${ }^{4}$ At the same time "all these old-fashioned vir-

Aristotle, Nicomachean Ethics, transl. W. D. Ross, in: The Complete Works of Aristotle, ed. J. Barnes, vol. 2, Princeton 1995, p. 1742.

2 Aristotle, Nicomachean Ethics, op. cit., p. 1748.

${ }^{3}$ Grotius, The Right of War and Peace, transl. A. C. Campbell A. M., New York-London 1901, p. 18.

4 J. Pomianowski, Wstęp [Introduction], in: I. Babel, Dziennik 1920 [Diary 1920], transl. J. Pomianowski, Warszawa 1998, p. 18 (transl. M. M. B.). 
tues - wrote Stefan Hertmans - fallen in the hell of the trenches of World War I [...] Cruelty and mass slaughter definitely changed the morality, vision of life, mentality and habits of this generation. From the battlefields of fragrant like pastures trample under foot, from soldiers that were saluting even in the moment of death, from the eighteenth-century painting idyllic military scenes, filled with hills and groups of trees, emerged strangled by mustard gas mental disorder, fields full detached limbs, full of old-fashioned type of human, which has been literally torn apart." ${ }^{5}$ Progress in this field was soon made by the Second World War and later by subsequent conflicts in which policy was becoming increasingly prominent. But in order not to fight savagely, already in the nineteenth century the international community began to work on the principles, rules and laws of war. To find a kind of reasoning and moderation in using weapon and proper measures international community agreed to begin the process of creation of the international humanitarian law. In its assumptions, it was not as restrictive as the Kantian idea of eternal/ perpetual peace, but in its foundations we can find echoes of this theory. ${ }^{6}$

Therefore, international community, arising only when states forming the international system have common interests and common values and believe that they are bound by a set of common principles, participate in the work of common institutions, and belong to one culture or civilization, ${ }^{7}$ recognizing the common purpose had to take appropriate actions. Aware not only of human nature but also focused on the development or war technique, taught by the experience of numerous conflicts, community started to work on international law, that could help find moderation and, in this way, protect civilization from the cruelty of war. Already in the nineteenth century, it was found that the killing became too cruel and resulted not only from direct combat between opponents.

${ }^{5}$ S. Hertmans, Wojna i terpentyna [War and Turpentine/org. Oorlog en terpentijn], transl. A. Oczko, Warszawa 2015, p. 332 (transl. M. M. B.).

6 Vide I. Kant, Perpetual Peace: A Philosophical Sketch, https://www.mtholyoke.edu/acad/intrel/kant/kant1.htm (2.02.2017).

7 Vide S. Huntington, The Clash of Civilizations and the Remaking of the Worlds Order, New York 2011. 
The states began to come up with some legal tools to protect themselves in the first place from the effects of the weapons that reach not only the enemy but also destroy the less accurately traced targets, and also the weapons that harm the adversary and extinguish unnecessary suffering.

One of the first of this type of acts is the St. Petersburg Declaration of 1868. This act applies to the resignation of the use in war of missiles containing less than 400 grams of explosive substance (so-called small-caliber bullets). ${ }^{8}$ Countries signing the Declaration were therefore aiming to investigate the expediency of banning certain missiles "in wars between civilized nations," all technical restrictions being "caused by the requirements of humanity." Thus, beyond the practical dimension, there is an ethical dimension in the law, reminding of the value and dignity of human life. Bearing in mind the historical experience of the peoples, it was also emphasized that "the progress of civilization should have the effect of alleviating as much as possible the calamities of war." of reasoning and looking for a proper measure, understood in the spirit of the golden mean seemed to be present even in this early acts and considerations. In line with these ideas, the aim of the war was not to bring the other country into a fall, not to deprive it of its future/culture and not to massacre all of its citizens, but to weaken the armed forces so that the aggressive nation that began its military operations could not wage war. The restrictions imposed by the Declaration made it possible to believe that, in order to achieve that goal, the fighters would not use weapons that unnecessarily aggravate human suffering or "make inevitable death," which in turn meant violating fundamental human rights.

States that has signed the Declaration went further. They not only agreed not to use in the war the missiles mentioned above and invited other nations to sign the document but left the right to the next agreements and exacerbations of the already existing regulations, bearing in mind the improvements that science can make in the field of armaments.

8 St. Petersburg Declaration of 1868, https://ihl-databases.icrc.org/applic/ihl/ihl.nsf/Article.xs p?action=openDocument\&documentId=568842C2B90F4A29C12563CD0051547C (1.20.2017).

9 St. Petersburg Declaration of 1868, op. cit. 
It was difficult not to assume that an increasingly evolving technique would not leave the war on its own, and that countries would not choose to exploit new discoveries to create ever more sophisticated and dangerous weapons. Future war - as expected even in the nineteenth century should be able to reconcile their basic needs with human rights. And while we know that history has written in this regard quite different scenarios, further legislation specifying the types and rules for using specific weapons has become a reality.

Talks about arms reduction and the need for peaceful coexistence have flared up again when, in 1898, Tsar Nicholas II, inspired by Russian consciousness, delayed the issue of military ministers of war, foreign affairs and finance, proposed holding a conference on arms confinement. „Car with an olive branch," said Vienna, "is something new in history." ${ }^{10}$ After months of negotiations, the conference venue chosen Hague. During the First Hague Conference debates were held on three commissions: armaments, rules of war and arbitration, and at the second conference (1907) a commission on maritime law was added. There were elaborated solutions concerning, inter alia, the civilian rights of defense, the treatment of prisoners and spies, the prohibition to the use of poisons and deceit, the ban on bombing of open cities, the rules for using the white flag, or conditions of occupation of hostile territory. ${ }^{11}$ The result of the first conference were three conventions, while the second - held in 1907 - have developed thirteen conventions.

When analyzing solutions to reduce arms, it is worth noting that successive solutions came relatively soon after the Petersburg Declaration. Thus, the use of splintering and gas bullets (The Hague 1899), balloon shunting and explosives (The Hague 1907), the use of poisonous gas, poisonous and bacteriological agents (Geneva 1925) were soon banned. And while they worked in the spirit of rational thought, trying to impose moderation on warfare and the beginning of the arms race, often,

10 B. W. Tuchman, The Proud Tower: A Portrait of the World Before the War, 1890-1914, New York 1966, p. 298.

11 B. W. Tuchman, The Proud Tower..., op. cit., p. 298. 
however, the law did not affect the actual operation of the armed forces. "Grenades, dense gas and tank flotillas - trampling, fatigue, death" ${ }^{2}$ wrote about the atrocities of the Great War, Erich Maria Remarque. When soldiers fell in the trenches one after the other, when they were hurting, "suffering excessively" or "dying not necessarily," they were lying in wartime hospitals, they did not remember, or perhaps they simply did not know anything about the existing, established laws. Did anyone seek rational justification? Their right and duty was to fight, and it was the fight that made them cruel at the cruelty. Unintentionally often, senselessly, and finally and unlawfully. Only the order of conscience, thought sometimes forced for too long moment free from killing, let to see a man in the fallen enemy. However, in order to see the humanity of the defeated enemy, it took a moment to think, and there was simply no time for it on the fronts of the Great War. At that time, war was "an endless monotony of misery, diversified by terrible tragedies, not silver-shining bayonets, or trumpets in the morning sun." ${ }^{33}$ And yet, this awareness opened up the moderation and rational application of the law. Further wars brought new challenges and international law was not always able to keep pace with the technical development and the cruel "fantasy" of the armed states. Bearing in mind the war practice, but also looking forward to the future, the next acts and conventions concern, inter alia: the prohibition of research, production and stockpiling of biological and toxic weapons (London, Moscow, Washington 1972), prohibition of conventional weapons causing excessive suffering or irreversible effects (Geneva 1980), prohibition or restriction of the use of mine-traps (Geneva 1996) and later also anti-personnel mines (Oslo 1997). But in addition to the technical / hardware development of war, other challenges have not escaped, pointing to the need for greater legal and ethical legitimization

12 E. M. Remarque, Na zachodzie bez zmian [All Quiet on the Western Front], transl. S. Napierski, Stalinogród (Katowice) 1956, p. 97 (transl. M. M. B.).

${ }^{13}$ H. Barbusse, Ogień [The Fire], transl. Zofia Jaremko-Pytowska, Warszawa 1959, p. 371 (transl. M. M. B.). 
of the issue of conducting warfare and dealing with enemies, allies, and the civilian population.

The first document, which in the international scale, in a very precise way regulates the laws and customs of land warfare, is the Hague Convention (Hague IV) on Laws and Customs of War on Land from 1907. ${ }^{14}$ It clearly defines, above all, who is to be considered a combatant, thus settling the question of the civilian population. When there is no doubt about the combatant, we will recognize a professional soldier or of a compulsory or voluntary (because it was still) abduction, the main problem occurred in the case of people not belonging to the army. While under the Hague IV, a soldier has the duty to stand out with a uniform or a badge, may bear arms and must obey war customs, there are doubts about the distinction between civilians and so-called common troops and unmarried volunteer troops. Thus, according to the Hague IV, these same formations, as well as the soldiers who join the army, have identical responsibilities and rights. Moreover, according to Article 2 of the Annex to the Convention "the inhabitants of a territory which has not been occupied, who, on the approach of the enemy, spontaneously take up arms to resist the invading troops without having had time to organize themselves in accordance with Article 1, shall be regarded as belligerents if they carry arms openly and if they respect the laws and customs of war." ${ }^{\prime 15}$ Thus, the armed conflict-making community voluntarily renounces the protection and rights of the civilian population, thereby passing under military jurisdiction.

However, it must not be forgotten that the armed forces are not the only ones who decide to take direct action. In addition to the army we have and non-combatant war workers, subjected to identical requirements and laws as soldiers. The latter group includes journalists, war correspondents, doctors, clergy, all kinds of military service providers, and wounded who are no longer capable of active combat as a result of

14 Laws and Customs of War on Land (Hague IV), 18.10.1907, http://avalon.law.yale.edu/20th century/hague04.asp (1.23.2017).

15 Laws and Customs of War on Land (Hague IV), op. cit. 
the fight. And although the responsibilities and activities undertaken by representatives of both groups is fundamentally different, in every position, they have the same rights. A good example, strongly emphasized by international law, is the situation of prisoners of war (both fighters and non-combatants). The first legal requirement - the ethical duty of the captives - is to provide humanitarian treatment. Here the signatories of Hague IV and the Annex indicate the possibility of human rights abuses. So when internment turns out to be necessary, prisoners must be treated with the right dignity and their rights, whether property or religion, cannot be violated in any way. The law also allows prisoners to work (paid), provided that it is not used for war purposes and even released under the word of honor. Patients and injured were also particularly protected. ${ }^{16}$ But apart from securing the rights and quite precisely distinguishing the civilians from the fighters, the Annex carries the entire catalog of obstructions that the war is protected. Once again, they are anchored in human rights, which is becoming the main focus of the legislative act. It is forbidden to kill or wound another in a treacherous manner, in an unfair fight, or in the way of deception, and even more so when he surrenders and as "voluntarily powerless" he will wait for the victorious grace. It also prohibits psychological violence and the belief that the legal conditions of war are of minor importance. It is forbidden to "declare that no quarter will be given." ${ }^{\text {17 }}$ The most important units, as before the others, however, appear to be that "family honour and rights, the lives of persons, and private property, as well as religious convictions and practice, must be respected." 18

Exhaustion not only ceases to be an unwritten law that has been used by the cruel invaders for centuries, but is legally forbidden. And while the Great War, and later the Polish-Bolshevik war, that were described by Isaac Babel, had nothing to do with legal restrictions, that legal and

16 The Annex refers here to The Geneva Convention of 1906. Further records and details will be found in The Geneva Convention of 1949, which, given the tremendous experience of World War II, precisely defines these issues.

17 Laws and Customs of War on Land (Hague IV, Annex), op. cit., Art. 23.

18 Laws and Customs of War on Land (Hague IV, Annex), op. cit., Art. 46. 
ethical prohibition extends beyond the end of the biological survival of man or the preservation of his species. What is more important, the signatories of the Annex noticed not only the value of a single life, but also the threat that war has for the whole civilization heritage. Hence, in Article 27, it is mentioned about its protection and non-targeting of attacks in places not related to war activities, such as "buildings dedicated to religion, art, science, or charitable purposes, historic monuments, hospitals, and places where the sick and wounded are collected." ${ }^{19}$ However, their protection - as demonstrated by successive wars - is inadequate. Both the man and the products of his culture became the object of great helplessness and thoughtlessness, and later of a very concrete, planned, even methodical destruction and extermination. It seems therefore that the creators of the pre-war legal acts did not fit in the head of the war thrust, covering first the Old Continent, later practically the whole world. In the wildest imaginations, the civilized nations could not have made the technique and science of humanity the ultimate threat. Commitment to reason and the need for moderation were found only in the framework of the reflection that came after the next war.

In the light of World War II it was necessary to redefine previously known concepts, to clarify laws (not invalidating earlier international arrangements, but rather extending them to new war experience). Here are all conventions, contracts and rights have been broken. Nazi Germany, militarized Japan, and the Soviet Russians did not respect the right of liberty, property, freedom of religion, did not appreciate human life, and the obligation to act in moderation was alien to them. Faced with the unimaginable cruelty, technical improvement of the army, and finally the denial of human dignity and the planned elimination of entire nations, it was necessary to revise the applicable laws. In keeping with the spirit of previous conventions, they were rewritten almost anew, adding the experience of the recent hekatombs. In 1948, the international community adopted in Paris the Universal Declaration of Human Rights, 1949 brought more Geneva conventions: The Third Geneva Convention

19 Laws and Customs of War on Land (Hague IV, Annex), op. cit., Art. 27. 
relative to the Treatment of Prisoners of War and The Fourth Geneva Convention relative to the Protection of Civilian Persons in Time of War. Five years later, the nations added to the catalog of their rights signed in The Hague Convention for the Protection of Cultural Property in the Event of Armed Conflict.

Bearing in mind that "disregard and contempt for human rights have resulted in barbarous acts which have outraged the conscience of mankind, and the advent of a world in which human beings shall enjoy freedom of speech and belief and freedom from fear and want has been proclaimed as the highest aspiration of the common people." ${ }^{20}$ The international community has opted for the specific renewal and refinement of human rights already described in The Charter of the United Nations. ${ }^{21}$ This is how the Universal Declaration of Human Rights came into being. Until 1966, it was only a UN resolution, but since its adoption it has traditionally been recognized as a law. Respecting its rights, already inherently human, was a prerequisite for a postwar world in which people would coexist peacefully. Without them it would be impossible to develop friendly relations between nations, and above all to restore faith in man, in his dignity, worth, freedom and rights. To inalienable human rights, in addition to already mentioned, included, among others: the right to life, liberty and security, to freedom of expression, religion, conscience and opinions, the right to work, to adequate standard of living, to learn and to participate in culture. The international community has agreed that "all human beings are born free and equal in dignity and rights. They are endowed with reason and conscience and should act towards one another in a spirit of brotherhood,"2 "without distinction of any kind, such as race, colour, sex, language, religion, political or other opinion, national or social origin, property, birth or other status" ${ }^{23}$ and equal in using reason and using ethical sense. No one can be detained

\footnotetext{
20 Universal Declaration of Human Rights, Preamble, http://www.un.org/en/universal-declaration-human-rights/index.html (23.01.2017).

${ }^{21}$ Charter of The United Nations, http://www.un.org/en/charter-united-nations/(23.01.2017).

22 Universal Declaration of Human Rights, op. cit., Art. 1.

23 Universal Declaration of Human Rights, op. cit., Art. 2.
} 
without trial, tortured or humiliated. No one can interfere in the private life of the individual. The above-mentioned laws will be binding for subsequent postwar documents that will refer to the principles, rights and freedoms „defined” by the Declarations. It is the dignity and the broadly understood humanitarian treatment that turn out to be key concepts for both the already mentioned Geneva Conventions. The first of the 1949, the so-called. The Third Geneva Convention (August 12, 1949), defines the ways in which prisoners of war are treated. In many points it details The Annex to The Hague Convention of 1907, directly defining the behavior that should occur in specific cases.

Bearing in mind the experiences of the Second World War, in the beginning articles The Third Geneva Convention emphasizes the way people should refer to non-combatants, including humanitarian duty, regardless of race, religion, gender, possessions etc., which excludes discrimination and segregation. The Convention presupposes their broad protection by not allowing to host them, nor does it allow any assassination on their lives, inviolability or personal dignity. ${ }^{24}$ Recalling earlier definitions of combatants and civilians, the Convention emphasizes that prisoners of war can only become members of the armed forces (and therefore soldiers, members of the militia, volunteer units and resistance), accompanying persons (as defined in the Annex to Hague Convention) and "Inhabitants of a non-occupied territory, who on the approach of the enemy spontaneously take up arms to resist the invading forces, without having had time to form themselves into regular armed units, provided they carry arms openly and respect the laws and customs of war." ${ }^{25}$ Importantly, a prisoner cannot be physically maimed or subjected to medical and scientific experience, which was commonly practiced in German labor camps during World War II. The international community, aware of these events, forbade - at every stage of the captivity, from the

24 Convention (III) relative to the Treatment of Prisoners of War, Geneva, 12.08.1949, Art. 3, https://ihl-databases.icrc.org/applic/ihl/ihl.nsf/Treaty.xsp?documentId=77CB9983BE01D004C12 563CD002D6B3E\&action=openDocument (24.01.2017).

25 Convention (III) relative to the Treatment of Prisoners of War, op. cit., Art. 4. 
moment of arrest, through interrogation and imprisonment or prison camp - of any physical or psychological violence against prisoners, particularly torture, mutilation or any kind of coercion.

A man who has fallen into captivity, the Convention does not deprive any of the rights that he owes thanks to his humanity. Although he loses his personal freedom and remains imprisoned, he does not lose his dignity, the right to own property, profess his religion and practice, nor to intellectual, cultural, educational or sporting activities. The prisoner also has the right to communicate with the outside world and thus to receive free correspondence and to receive mailings. The Convention strictly sets out the conditions of imprisonment itself, including issues related to the accommodation and boarding of prisoners. Housing warming, moisture protection, lighting, rations of food, water and tobacco, the need to provide clothing and footwear suitable for the climate, and adequate hygiene and medical care - all is legally sanctioned. The work of captives, a thorny issue and so important for legal regulation after World War II is allowed by the Convention, but must be carried out in a timely manner and in a manner similar to the conditions of doing the same work in peace. Under Art. 78 prisoners have the right to complain both on the terms of imprisonment and on the work. It is not, however, that the prisoners are not under any obligation. The Convention obliges them to adhere to the camp regulations, as well as punish them (through fines, revocation of privileges, forced labor, detention). ${ }^{26}$

Similar prohibitions, however, relating to methods of treating civilians during the war, introduced the Fourth Geneva Convention. ${ }^{27}$ In relation to civilians, it prohibits attacks on life, torture, mutilation, assault on personal dignity, hostage taking, and the use of any kind of cruelty (physical and mental). Bearing in mind the experience of the Second World War, the Convention stresses the need for respect for religious practices, the

${ }^{26}$ Convention (III) relative to the Treatment of Prisoners of War, op. cit., Art. 89.

27 Convention (IV) relative to the Protection of Civilian Persons in Time of War, Geneva, 12.08.1949, https://ihl-databases.icrc.org/applic/ihl/ihl.nsf/Treaty.xsp?documentId=AE2D398352C5B028C125 63CD002D6B5C\&action=openDocument (24.01.2017). 
dignity of the person, honor, family rights, and customs, and the special protection against rape, intimidation, insults and "public curiosity" that jeopardize one's privacy. The document also raises the issue already mentioned in the Universal Declaration of Human Rights, namely the prohibition of segregation or discrimination resulting from any reason. ${ }^{28}$ Civilians, and therefore persons who do not participate in military activities in any way and do military work, are also to be protected from the effects of war, and in special cases (for sick, injured, cripples, old people, children up to fifteen, pregnant women and mothers of children up to the age of seven), special zones or sanitation zones should be designated to facilitate their protection. ${ }^{29}$

However, in spite of this law, military practice often goes against civilians and non-combatants. Although civilians have always suffered during the war, never before has mass killing been the target of war. Today, however, it is the civilians who are the first target of the attack. "Civilians are being killed to get them out like in Bosnia, to simply kill them like in Rwanda or for one reason or another, as is happening in Chechnya. Or they kill civilians when they are not able to kill the soldiers, and yet one have to kill to put the war machine in motion" ${ }^{30}$ wrote war correspondent Jean Hatzfeld. How, if not purpose and precision, explain the situation in which a flier shoots a raft full of civilians crossing a river? How to explain the labor camps and the selection of those who survived longer than others? How to understand the activities of totalitarian regimes that do not respect the rights of their citizens and condemn them to humiliation, suffering and death? Ethics, understood even as a technical team of the notion of good and evil, have nothing to say. What about the law, reason or moderation? What happens to humanity that not only does not apply, but does not even seek the golden measure?

${ }^{28}$ Vide Convention (IV) relative to the Protection of Civilian Persons in Time of War, Art. 27 and Art. 34.

29 Vide Convention (IV) relative to the Protection of Civilian Persons in Time of War, Art. 14.

30 J. Hatzfeld, Linia zanurzenia [Line of Immertion], przekł. J. Giszczak, Warszawa 2009, p. 114 (transl. M. M. B.). 
Such violations of the rules of both Geneva Conventions, understood as acts detrimental to persons or property protected by it - and therefore "willful killing, torture or inhuman treatment, including biological experiments, willfully causing great suffering or serious injury to body or health, compelling a prisoner of war to serve in the forces of the hostile Power, or willfully depriving a prisoner of war of the rights of fair and regular trial prescribed in this Convention" ${ }^{31}$ and in the case of civilians also "unlawful deportation or transfer or unlawful confinement of a protected person, compelling a protected person to serve in the forces of a hostile Power [...], taking of hostages and extensive destruction and appropriation of property, not justified by military necessity and carried out unlawfully and wantonly"32 are not only forbidden but also punishable by criminal sanctions. The document imposes on the Contracting Parties not only the obligation to issue national provisions on such sanctions and orders for the search and even prosecution of persons violating the provisions of the Convention, but also to prosecute them irrespective of their nationality. Thus, war crimes were recognized as transnational crimes under the jurisdiction of international tribunals (such as the International Court of Justice and the International Criminal Court). These, in turn, are based on their own general statutes, as well as documents prepared for the legal development of particular cases of war crimes, genocide, crimes against humanity and crimes of aggression. ${ }^{33}$ Also, the Conventions them-

31 Convention (III) relative to the Treatment of Prisoners of War, op. cit., Art. 130.

32 Convention (IV) relative to the Protection of Civilian Persons in Time of War, op. cit., Art. 147.

33 Apart from the Statute of the International Court of Justice and The Rome Statute of the International Criminal Court, we have a number of documents / statutes defining criminal proceedings in cases of individual wars and armed conflicts on an international, interstate and local level. Separate documents define: issues of prosecution and punishment of war criminals (Agreement for the Prosecution and Punishment of the Major War Criminals of the European Axis, and Charter of the International Military Tribunal, London, 8.08.1945), prevention of genocide (Convention on the Prevention and Punishment of the Crime of Genocide) New York, 9.12.1948), non-use of limitation of war crimes (Convention on the Non-Applicability of Statutory Limitations to War Crimes and Crimes Against Humanity, New York, 26.11.1968), and criminal prosecution in cases such as the war in the Balkans and Genocide in Rwanda (Statute of the International Criminal Tribunal for former Yugoslavia, New York, 25.05.1993, and Statute of the International Tribunal for Rwanda, New York, 8.11.1994). 
selves contain records that they are not the only documents defining war laws. Apart from international documents, they allow the emergence of additional interstate special agreements, which deal with specific issues or conflicts, but their provisions cannot be less favorable to prisoners and civilians than those contained in the Conventions. The rights and obligations enshrined in the Geneva Conventions are therefore superior to any later war law and must be rooted in them.

It is worth noting that while preparing the basis for the international control of the armed forces, the two Conventions, one by one, account for the "sins" and negligence that the Second World War committed to both prisoners and civilians. Adopting these documents means not only making efforts but making specific decisions to prevent the repetition of similar actions in future armed conflicts. That is why the documents point such detailed guidelines, prescribing almost every predictable aspect of the war fate of civilians and captives, trying to ensure the best protection of their rights. For this reason, the very volume of each of these documents is about ten times greater than the Annex to The Hague Convention of 1907, which did not know such terms as a labor camp, compulsory export or ghetto, nor assumed the possibility of genocide understood as planned extermination conducted methodically, in a manner condemned by cruelty, hatred and thoughtlessness.

When we consider the intervention, the commitment is not in an aggressive war that comes to our country, but in a war that seems to pose no direct threat to us, moderation is necessary. But how to apply the principle of moderation and act in the spirit of reason, when against the aggressive regime, lacking internal legitimacy that harms its own citizens, thereby violating all applicable laws, has already used any "pre-war" means? How to find golden mean in war time? I will address this issue in the second part of this article. 


\section{Literature}

Aristotle, Nicomachean Ethics, transl. W. D. Ross, in: The Complete Works of Aristotle, ed. J. Barnes, Princeton University Press 1995.

Babel I., Dziennik 1920 [Diary 1920], transl. J. Pomianowski, Warszawa 1998.

Barbusse H., Ogień [The Fire], transl. Z. Jaremko-Pytowska, Warszawa 1959.

Charter of The United Nations, http://www.un.org/en/charter-united-nations/(23.01.2017).

Convention (III) relative to the Treatment of Prisoners of War, Geneva, 12.08.1949, Art. 3, https://ihl-databases.icrc.org/applic/ihl/ihl.nsf/Treaty.xsp?documentId=77CB9983B E01D004C12563CD002D6B3E\&action=openDocument (24.01.2017).

Convention (IV) relative to the Protection of Civilian Persons in Time of War, Geneva, 12.08.1949, https://ihl-databases.icrc.org/applic/ihl/ihl.nsf/Treaty.xsp?documentId $=$ AE2D398352C5B028C12563CD002D6B5C\&action=openDocument (24.01.2017).

Grotius, The Right of War and Peace, transl. A. C. Campbell A. M., New York-London 1901. Hatzfeld J., Linia zanurzenia [Line of Immertion], przekł. J. Giszczak, Warszawa 2009. Hertmans S., Wojna i terpentyna [War and Turpentine/org. Oorlog en terpentijn], transl. A. Oczko, Warszawa 2015.

Huntington S., The Clash of Civilizations and the Remaking of the Worlds Order, New York 2011.

Kant I., Perpetual Peace: A Philosophical Sketch, https://www.mtholyoke.edu/acad/intrel/ $\mathrm{kant} / \mathrm{kant} 1 . \mathrm{htm}$ (2.02.2017).

Laws and Customs of War on Land (Hague IV), 18.10.1907, http://avalon.law.yale.edu/ 20th_century/hague04.asp (23.01.2017).

Remarque E. M., Na zachodzie bez zmian [All Quiet on the Western Front], transl. S. Napierski, Stalinogród (Katowice) 1956.

St. Petersburg Declaration of 1868, https://ihl-databases.icrc.org/applic/ihl/ihl.nsf/Article. xsp?action=openDocument\&documentId $=568842 \mathrm{C} 2 \mathrm{~B} 90 \mathrm{~F} 4 \mathrm{~A} 29 \mathrm{C} 12563 \mathrm{CD} 005154$ 7C (20.01.2017).

Tuchman B. W., The Proud Tower: A Portrait of the World Before the War, 1890-1914, New York 1966.

Universal Declaration of Human Rights, Preamble, http://www.un.org/en/universal-declaration-human-rights/index.html (23.01.2017). 


\section{Abstract \\ Reasoning and Moderation as Principles of International Humanitarian Law (Part 1)}

Thinking of war means facing ideas and theories much different than those known and good established in everyday life. Even well known concept demands redefinitions. Among ideas understood as intellectual tools of war one can indicate two crucial, accompanying each consideration about war as such. Those are moderation and reasoning. Both should be present in out thinking about war, no matter if we would analyze political, legal, ethical or humanitarian dimensions of war or - in the other hand - no matter if we would consider its meaning for whole community or life/fate of individual human being. The first part of this article focuses on theoretical considerations, while further analyzes will indicate the consequences that thinking in the spirit of moderation and reasoning has in theory and practice of international humanitarian law.

\section{Keywords}

humanitarian law, moderation, reasoning, war, values

\section{Abstrakt \\ Rozsądek i umiar jako podstawy międzynarodowego prawa humanitarnego}

Myślenie o wojnie oznacza stawianie czoła ideom i teoriom znacznie odmiennym od tych, które napotykamy w codziennym życiu. Nawet dobrze znane koncepcje wymagają redefinicji. Pośród idei, które możemy uznać za intelektualne narzędzia wojny, należy wskazać dwie zasadnicze, towarzyszące każdemu rozważaniu o wojnie jako takiej. Są to umiar i rozsądek. Obie powinny być obecne w myśleniu o wojnie, niezależnie od tego, czy analizie poddawany jest jej polityczny, prawny, etyczny czy ludzki wymiar; i z drugiej strony niezależnie od tego, czy rozważamy jej znaczenie dla całej wspólnoty czy dla życia/losu jednostki. Przedłożona tu pierwsza część artykułu skupia się na teoretycznych rozważaniach, podczas gdy dalsze analizy będą wskazywały na konsekwencje, jakie myślenie w duchu umiaru i rozsądku wnosi do prawa dotyczącego konfliktów zbrojnych. 


\section{Słowa klucze}

prawo konfliktów zbrojnych, rozsądek, umiar, wartości, wojna 